\title{
FGFR Inhibitor TAS-120
}

National Cancer Institute

\section{Source}

National Cancer Institute. FGFR Inhibitor TAS-120. NCI Thesaurus. Code C114283.

An orally bioavailable inhibitor of the fibroblast growth factor receptor (FGFR) with potential antineoplastic activity. FGFR inhibitor TAS-120 selectively and irreversibly binds to and inhibits FGFR, which may result in the inhibition of both the FGFR-mediated signal transduction pathway and tumor cell proliferation, and increased cell death in FGFRoverexpressing tumor cells. FGFR is a receptor tyrosine kinase essential to tumor cell proliferation, differentiation and survival and its expression is upregulated in many tumor cell types. 